\title{
The Relationships Between Egg Production, Age and The Hatching Traits of Pheasants
}

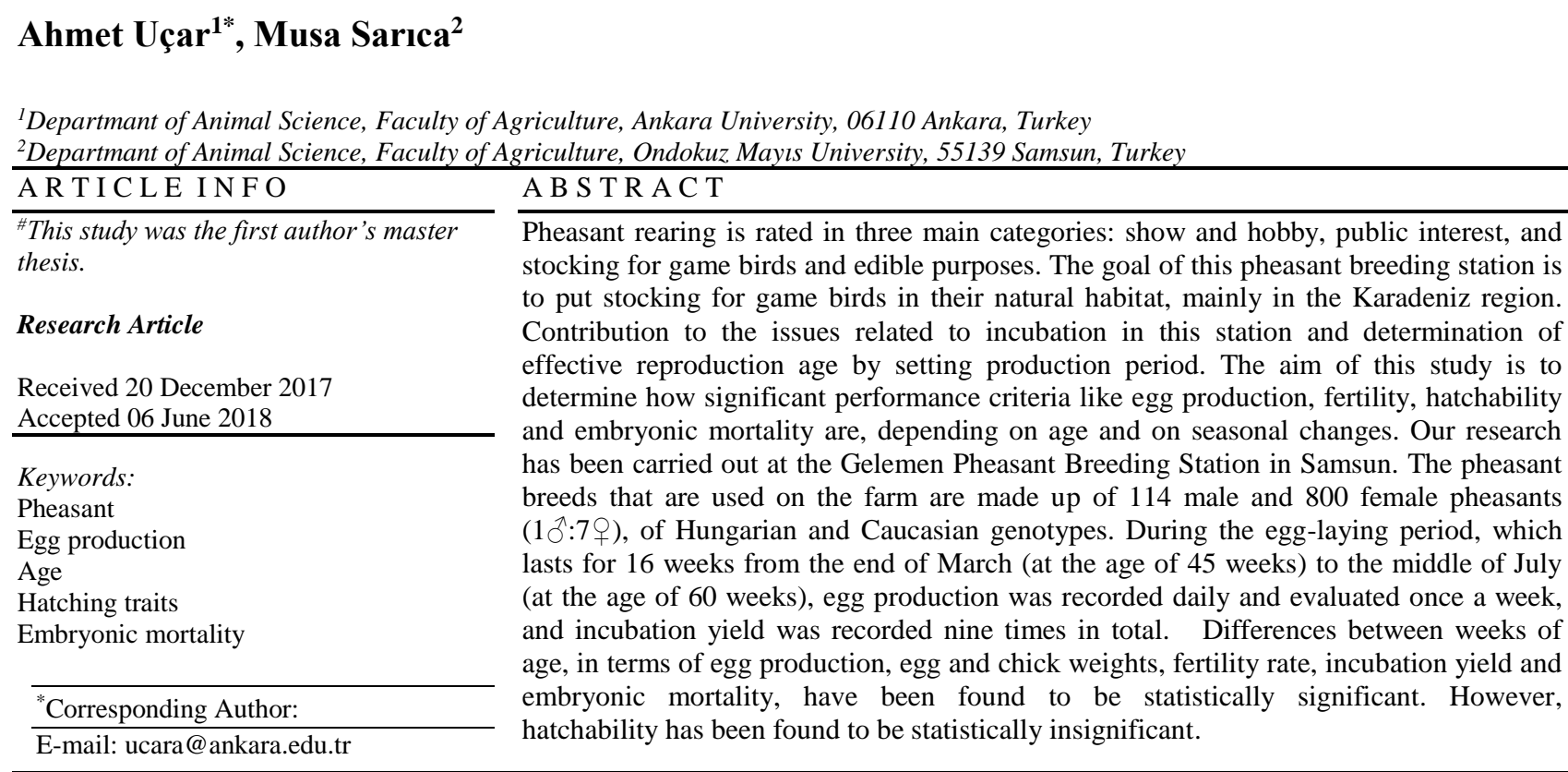

DOI: https://doi.org/10.24925/turjaf.v6i10.1311-1316.1765

\section{Introduction}

In recent years, interest in breeding and alternative poultry has become common because of a desire to be closer to nature. In particular, owing to an interest in birds that can be used in hunting, some growers have found breeding pheasant species to be a profitable venture. These initiatives were launched at a low level, enabling the creation of high-capacity pheasant breeding farms that grew over time (Yamak, 2015). Breeding game birds is rated in three main categories: show and hobby, public interest, and stocking for game birds and edible purposes (Scheid, 1986). Common pheasant varieties are produced for their meat and for hunting; because of this, they differ from other species. Jungle fowls, which are the ancestors of the chicken, are also members of the Phasianidae family. Their easy adaptation to various breeding conditions is a basic trait and they are produced all around the world (Scheid, 1986; Ucar et al., 2012). Pheasants are valuable for being a ground game animal for hunters and for their protein-rich meat and eggs. Also, because of the attractive appearance of their colors and feathers, different species are reared apart from their natural environment as a hobby or for sport. Pheasants arrived in Europe more than 1000 years ago from China, Japan and Anatolia (Long, 1981). In Kansas and also in Minnesota USA, about 100,000 to 150,000 hunters hunt 400,000 to
800,000 pheasants per season; this amounts to approximately 350,000 birds in a season (Llanas, 2014). Pheasants are useful creatures for humanity worldwide. By producing and managing pheasants, sustainable profit can be obtained with the help of economic inducements (Fuller and Garson, 2000).

Common pheasants are members of the family of Asian pheasants. In this species, which is polygamic every male has its own harem that contains 1 to 8 female(s) (Briganti et al., 1999). So while breeding, the male to female ratio must be kept at $1: 5,1: 6$ or $1: 7$ according to the type being reared. In some pheasant species this ratio is 1:8. Keeping breeding males and females seperate reduces the possibility of fighting (Cetin and Kirikci, 2000). Wild pheasants lay approximately 10 eggs for every 1 to 2 laying periods over a year (Sarica et al., 2003). The natural laying season that begins in spring, may be extended into winter by using artificial lighting. Thus, eggs can be obtained from the pheasants in every season of the year (Cetin and Kirikci, 2000), but, because of the male pheasants' readiness to mate only at certain periods of the year, the female pheasants can be artificially inseminated with $0.05 \mathrm{ml}$ of diluted semen applied twice a week (Sarica et al., 2003). Most of the eggs produced from the pheasants are green and brown; a 
few of them can be beige or blue. Owing to their poorer incubation performance, beige and blue eggs should be used as eggs for the table. But, this doesn't mean a huge production for general table pheasant egg consumption (Kirikci, 2012). There are many factors that affect hatchability. When producing pheasants, the most important factors affecting profitability are the pheasants breeding ability and hatchery performance, which means the number of chicks obtained from the eggs of a healthy female (Krystianiak et al., 2007). According to the age and seasonal changes, there have been some problems with pheasants with regard to egg productivity and hatchability.

This study investigated problems arising during incubation (fertility rate, hatchability, embryonic mortality, etc.), during the egg production in a laying period and their relationship to the ages of the pheasants. The results were evaluated to make suggestions for the current systems in use.

\section{Materials and Methods}

\section{Nutrition}

The feed material ingredients shown in Table 1, were used to feed the birds during their chick and hen periods. During the study, water and feed was given as ad libitum to all pheasants.

\section{Production System and Housing Conditions}

The study was conducted at the Gelemen Pheasant Breeding Station of the Ministry of Forestry and Water Affairs in Samsun between March and July 2013 during the 16-week laying period. The incubation process was carried out in a $66 \mathrm{~m}^{2}$ hatchery with 3 setter and 2 hatcher machines (Cimuka T-series), each one with a 2880 pheasant egg capacity. The breeders are placed on an 20 $\mathrm{m}^{2}$ each and made entirely of wire, in a ratio of $1 \delta^{\lambda}: 7$ ㅇ to the open breeding pens.

\section{Animal Material}

Hungarian (Ringed) and Local (Caucasian) genotype pheasants, bred using a mating ratio of $1 \delta^{\lambda}: 7 q_{+}-$the first hatched in May in 2012 - were used for the study. Because of deaths, the female pheasant numbers decreased to 780 by the end. The first eggs were layed at the end of March 2013. Before the laying period no lighting procedure was applied so that the first eggs started to be produced at the age of 45 weeks and the laying process continued until the second week of July. By this time, egg production had decreased and the breed flock was transferred to a conservation area for subsequent release.

\section{Eggs and Incubation}

Eggs were collected from the breeding pens twice a day (in the morning and in the afternoon) and hatched eggs loaded onto trays. Egg numbers were recorded daily. Eggs that were obtained from these breeds at 46 weeks were put into incubators every week, and 2880 eggs were put into each incubator. In the first 21 days of the incubation process, eggs were turned every 2 hours and kept at $37.7^{\circ} \mathrm{C}$ and $62 \%$ relative humidity. In the last 3 to 4 days of incubation, the heat was set to $37.7^{\circ} \mathrm{C}$ and the humidty was set from 85 to $90 \%$, but the eggs were not turned. All eggs were individually weighed from 49 weeks to determine the best eggs for incubation. In the trial, the incubation processes were performed 9 times up to the age of 54 weeks. From each batch, 150 to 200 chicks were randomly selected and their weights determined. Unhatched eggs were broken and classified to determine the stage of embryonic mortality (early, mid, late or pipped). With the help of these data, standard fertility rates, hatchability and embryonic mortality rates were identified along with early, mid, late and pipped embryo death rates. The parents weights were determined

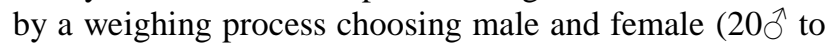
80 ) ) animals randomly, which were at the end of their breeding periods of 60 weeks.

\section{Statistical Analysis}

During the hatching studies, Chi-square analysis was applied to test the differences among parent ages - shown as percentages. Analyses were carried out on data primarily defined in percentage terms and using a nonparametric option. Significant tests were carried out within $\mathrm{P}<0.05$ confidence limits on the binary predicates. The Chi-square test values were calculated automatically so that there wasn't a specific limit. Values for the embryonic deaths were expected to be below 5\%; that's why Chi-square values were calculated using Fisher's Exact test, and the binary predicates were also derived according to Fisher's Exact test (Duzgunes et al., 1987; Ozdamar, 2002).

One-way variance analysis was performed to determine the weekly differences between the egg weights and chick weights. When comparing averages, the Duncan test was performed. SPSS analysis software (Version 20) was used in all comparisons by considering a $5 \%$ confidence limit.

Table 1 Feed - material ingredients of the feeds which were given to breed pheasants on different periods.

\begin{tabular}{l|ccc}
\hline \multirow{2}{*}{ Feed } & \multicolumn{3}{c}{ Usage Period } \\
\cline { 2 - 4 } & Chick (0-8 Weeks) & Poult (9-40 Weeks) & Laying (41-60 Weeks) \\
\hline Crude Protein (\%) & 19 & 14.5 & 16 \\
Crude Cellulose (\%) & 6 & 6 & 7 \\
Crude Ash (\%) & 8 & 8 & 13 \\
Calcium (\%) & $0.8-1.2$ & $1.0-1.5$ & $3.5-4.0$ \\
Phosphorus \%) & 0.5 & 0.40 & 0.33 \\
Lysine (\%) & 0.9 & 0.65 & 0.75 \\
Methionine (\%) & 0.4 & 0.33 & 0.47 \\
Metabolic Energy (ME Kcal/kg) & 2800 & 2750 & 2750 \\
\hline
\end{tabular}




\section{Results and Discussion}

Female breeding pheasants started egg production at 45 weeks of age at a hatching level of $6.17 \%$. Peak production was reached at 49 weeks with $72.07 \%$. The egg production, which started to decrease in later periods, declined to $5.30 \%$ at 60 weeks old (Table 2). The mean hatching egg weight was found to be $32.27 \mathrm{~g}$ from eggs produced during the laying period and where weekly weight differences were considered to be significant $(\mathrm{P}<0.05)$. The heaviest egg was produced at 52 weeks old age, and weekly weights were from 31.78 to $32.82 \mathrm{~g}$. The differences obtained in terms of the weights of the chicks during the incubation period were found to be significant $(\mathrm{P}<0.05)$ with the highest chick weight determined at the 48th week to be $22.54 \mathrm{~g}$. For the 9 incubations, the average chick weight was calculated to be $21.27 \mathrm{~g}$ (Table 2).

Egg production of pheasants differs according to genotype and rearing applications. Sarica et al. (2003) noticed that with the help of heterosis it is possible to get 170 eggs in a year, and 150 of them could be used for hatching. In the flock that was used in our study, breeding and production was not carried out in accordance with natural conditions, and although it is not possible to express the actual performance, during the egg-laying production period, figures of $45.36 \%$ and an average count of 50.53 was obtained (Table 2). Our study started seasonally in the last week of March, which is the beginning of the laying period for pheasants, and these findings were noticed by others (Gibes et al.,1974; Wise, 1995). It was also noticed, based on temperature and periods of light - especially in their natural environment where breeding takes place - the laying period can be started in April or in the weeks after (Krystianiak et al., 2007; Aktas, 2009). Even though the age at the onset of laying is specified as 35 to 40 weeks in published literature, the first eggs obtained from the pheasants were in their 45th week. With an appropriate lighting schedule, it was possible for female pheasants to lay at an earlier age, and their laying period can be extended up to 27 weeks (Mashally et al., 1983).

Kuzniacka et al. (2005) noticed that the laying period lasts for 103 days (15 weeks). Krystianiak et al. (2007) noticed that the earliest laying age was 282.6 days, that the 1-year-old females' laying period was 109.3 days which is 21 days longer than 2-year-old females - and the 1 -year-old females started laying between 3 rd to the 16 th April, whereas 2-year-old females started laying between the 1st to the 24th of April. For pheasants bred in extensive systems, the egg production was noted to be 40 to $45 \%$, and the egg count per female pheasant was calculated to be 65 (Yannakopoulos, 1992; Yilmaz, 2004).

There are some studies that noticed peak egg production in the 3rd week (Tserveni-Gousi and Yannakopoulos,1990), 4th week (Krystianiak et al., 2007), 6th week (Kuzniacka et al., 2005) and 7th week (Gibes et al., 1974). But some researchers' results showed peak egg production in the 5th week (Woodard and Snyder 1978; Usturoi 2008) following a rapid increase after the laying period started, that parallels our study. While Ustuori (2008) reaches peak egg production of $77.87 \%$, Kuzniacka et al. (2005) reaches a value as high as $90.49 \%$. While Kuzniacka et al. (2005) obtained an initial egg production of $7 \%$ and last week efficiency of $2 \%$, Ustuori (2008) calculated higher figures with initial egg production at $2.84 \%$ and last week production at $12.31 \%$. Pfaff et al. (1990) noticed egg production at a high value of $70 \%$ among the pheasants bred in open cages with rates of $1 \delta^{\lambda}: 19 q$. Usturoi (2008) recorded less egg production than this study at $44.35 \%$; Esen et al. (2010) noticed higher egg production in 1- and 2-year-old pheasants in the order of $47.58 \%$ and $53.27 \%$, but at $42.69 \%$ for 3 -year-old female pheasants.

Table 2 Egg production, egg weight and mean chick weight according to different laying ages

\begin{tabular}{|c|c|c|c|c|c|c|}
\hline \multirow{2}{*}{$\begin{array}{l}\text { Laying } \\
\text { Period } \\
\text { (week) }\end{array}$} & \multirow{2}{*}{$\begin{array}{l}\text { Laying } \\
\text { age } \\
\text { (week) }\end{array}$} & \multicolumn{3}{|c|}{ Egg production } & \multirow{2}{*}{$\begin{array}{c}\text { Egg weight } \\
(\mathrm{g}) \\
\bar{x} \pm \mathrm{S} \bar{x} \\
\end{array}$} & \multirow[b]{2}{*}{$\begin{array}{c}\text { Chick weight (g) } \\
\bar{x} \pm \mathrm{S} \bar{x}\end{array}$} \\
\hline & & $\begin{array}{c}\text { Eggs / Bird / } \\
\text { Week }\end{array}$ & $\begin{array}{l}\text { Eggs / Bird / } \\
\text { Cumulative }\end{array}$ & $\begin{array}{c}\% \\
\text { (per week) }\end{array}$ & & \\
\hline 1 & 45 & 0.42 & 0.42 & $6.17^{g}$ & $31.78 \pm 2.85^{\mathrm{c}}$ & \\
\hline 2 & 46 & 3.56 & 3.98 & $51.16^{b c}$ & $31.85 \pm 2.90^{\mathrm{c}}$ & $21.85 \pm 1.91^{b}$ \\
\hline 3 & 47 & 4.51 & 8.49 & $64.57^{a b}$ & $32.10 \pm 2.48^{b c}$ & $20.73 \pm 1.97^{\mathrm{d}}$ \\
\hline 4 & 48 & 4.94 & 13.43 & $70.73^{\mathrm{ab}}$ & $32.29 \pm 2.61 \mathrm{abc}$ & $22.54 \pm 3.49^{\mathrm{a}}$ \\
\hline 5 & 49 & 5.04 & 18.47 & $72.07^{\mathrm{a}}$ & $32.35 \pm 2.32 \mathrm{abc}$ & $20.86 \pm 1.62^{\mathrm{cd}}$ \\
\hline 6 & 50 & 4.94 & 23.41 & $70.88^{a b}$ & $32.54 \pm 2.34^{a b}$ & $21.45 \pm 2.12^{b c}$ \\
\hline 7 & 51 & 4.56 & 27.97 & $65.47^{a b}$ & $32.28 \pm 2.45 \mathrm{abc}$ & $20.75 \pm 2.08^{\mathrm{d}}$ \\
\hline 8 & 52 & 4.57 & 32.54 & $65.49^{a b}$ & $32.82 \pm 2.68^{a}$ & $20.98 \pm 1.89^{\mathrm{cd}}$ \\
\hline 9 & 53 & 4.33 & 36.87 & $62.06^{\mathrm{ab}}$ & $32.17 \pm 2.46^{b c}$ & $21.18 \pm 2.05^{\mathrm{cd}}$ \\
\hline 10 & 54 & 3.67 & 40.54 & $52.55^{\mathrm{ab}}$ & $32.34 \pm 2.26^{\mathrm{abc}}$ & $21.09 \pm 1.89^{\mathrm{cd}}$ \\
\hline 11 & 55 & 2.91 & 43.45 & $41.79^{\mathrm{cd}}$ & $32.22 \pm 2.30^{a b c}$ & \\
\hline 12 & 56 & 2.32 & 45.77 & $33.57^{\mathrm{cde}}$ & $32.52 \pm 2.45^{\mathrm{ab}}$ & \\
\hline 13 & 57 & 1.94 & 47.71 & $27.97 \mathrm{de}$ & & \\
\hline 14 & 58 & 1.55 & 49.26 & $22.66^{\text {ef }}$ & & \\
\hline 15 & 59 & 0.92 & 50.18 & $13.33 \mathrm{fg}$ & & \\
\hline 16 & 60 & 0.35 & 50.53 & $5.30^{\mathrm{g}}$ & & \\
\hline & Mean & 3.16 & - & 45.36 & $32.27 \pm 2.52$ & $21.27 \pm 2.24$ \\
\hline
\end{tabular}

a,b,c: Differences among the egg efficiencies are shown by different letters according to the results of Chi-square analyses and the Duncan test results which are shown with different letters are significant $(\mathrm{P}<0.05)$. 
Table 3 Fertility, hatchability of fertile eggs and hatchability rates according to laying age (\%)

\begin{tabular}{c|cccc}
\hline $\begin{array}{c}\text { Incubation } \\
\text { Period }\end{array}$ & $\begin{array}{c}\text { Laying Age } \\
\text { (weeks) }\end{array}$ & Fertility Rate & $\begin{array}{c}\text { Hatchability of } \\
\text { Fertile Eggs }\end{array}$ & $\begin{array}{c}\text { Hatchability of } \\
\text { Total Eggs }\end{array}$ \\
\hline 1 & 46 & $84.48^{\mathrm{a}}$ & 80.49 & $68.00^{\mathrm{a}}$ \\
2 & 47 & $80.49^{\mathrm{a}}$ & 86.36 & $69.51^{\mathrm{a}}$ \\
3 & 48 & $85.41^{\mathrm{a}}$ & 81.12 & $69.28^{\mathrm{a}}$ \\
4 & 49 & $81.95^{\mathrm{a}}$ & 83.72 & $68.60^{\mathrm{a}}$ \\
5 & 50 & $82.23^{\mathrm{a}}$ & 90.06 & $74.06^{\mathrm{a}}$ \\
6 & 51 & $79.97^{\mathrm{a}}$ & 86.51 & $68.18^{\mathrm{a}}$ \\
7 & 52 & $77.32^{\mathrm{a}}$ & 88.02 & $60.94^{\mathrm{a}}$ \\
8 & 53 & $74.02^{\mathrm{a}}$ & 82.32 & $31.03^{\mathrm{b}}$ \\
\hline
\end{tabular}

a,b,c: According to the Duncan test results, the differences between egg production shown by different letters are remarkable.

Table 4 Embryonic mortality rates related to the laying ages (\%)

\begin{tabular}{c|ccccc}
\hline \multirow{2}{*}{$\begin{array}{c}\text { Incubation } \\
\text { Period }\end{array}$} & $\begin{array}{c}\text { Breeder Age } \\
\text { (week) }\end{array}$ & Early & Middle & Late & Pipped \\
\cline { 3 - 5 } & 46 & 3.22 & 7.01 & 4.73 & 4.55 \\
2 & 47 & 3.60 & 4.73 & 3.60 & 1.70 \\
3 & 48 & 1.80 & 7.19 & 5.76 & 4.14 \\
4 & 49 & 3.64 & 4.60 & 4.02 & 4.02 \\
5 & 50 & 1.26 & 3.63 & 4.42 & 0.63 \\
6 & 51 & 1.73 & 3.47 & 4.43 & 3.85 \\
7 & 52 & 1.86 & 2.69 & 6.40 & 1.03 \\
8 & 53 & 1.85 & 5.28 & 6.60 & 3.96 \\
9 & 54 & 0.94 & 4.72 & 7.55 & 1.89 \\
\hline
\end{tabular}

Genc and Ozbey (2013) noted egg weight averages that were produced by 36 to 40,41 to 44,45 to 48 and 49 to 53 week-old pheasants to be $28,67,30.08,31.04$ and $31,85 \mathrm{~g}$, respectively. Similarly, Usturoi et al. (2010) obtained egg weights of the order of 28.64, 31.02, 31.87 and $32.16 \mathrm{~g}$, which they collected during the laying period in weeks $1,5,8$ and 13 , and the average egg weight was $30.92 \mathrm{~g}$; these results are lower than our study. The flocks that we used in our study started laying at an older age than usual - as recorded in published literature - and it is possible that caused a positive effect and heavier weights. But, Kuznizcka et al. (2005) remarked on variable egg weights and also noticed that as the weeks progressed, laying showed a downward trend as in our study. They measured the eggs in the laying period's 3rd, 5th, 7th, 9th, 11 th and 13th weeks at $31.4,31.0,31.0,31.8$ and $30.7 \mathrm{~g}$, and they reported the average egg weight to be $31.3 \mathrm{~g}$. Although the examples given above were carried out for different feeding, rearing, housing and environmental conditions, it was seen that their average rates are lower than our study. Sarica and Karacay (1994) reported the daily chicks' weights to be 24.75 g. Cetin et al. (1997b) measured the chick weight to be $21.97 \mathrm{~g}$, which they obtained from incubation breeding in an intensive system, and this result is higher than our study. Kuzniacka et al. (2005) though, reported the weights lower at 21.5, 20.7, $20.2,20.3,20.4 \mathrm{~g}$ and the average weight to be $20.7 \mathrm{~g}$, the chicks - which they produced from eggs during laying periods in the 3rd, 5th, 7th, 9th and 11th weeks paralleled our study.

All averaged results related to the hatchery operations, such as fertility rate, hatchability of fertile eggs and hatchability were measured to be $75.82,84.83$ and $64.30 \%$, respectively. In this study, the highest fertility rate was found in 48-week-old eggs. After the 48th week the fertility rate decreased. Fertility rates in the hatchery measured from $36.55 \%$ to $85.4 \%(\mathrm{P}<0.05)$. In the study, a significant decline occurred in the fertility rate in the last incubation, and accordingly, on the hatchability. The highest hatchability rate for fertile eggs gained were produced from 50-week-old birds at $90.06 \%$ (Table 3).

It is thought that the high fertility rates obtained in this study were related to the age of the breeding flock. Ipek and Yilmaz (2006) calculated fertility rates of 78.6 and $83.3 \%$ from the same flock which they bred at a rate of $1 \delta^{\top}: 8$ ? and produced eggs taken in the 1st and 2nd laying periods; these results are higher than our study. Esen et al. (2010), remarked on the hatchability of fertile eggs which were produced at a rate of $1 \delta: 4 q$ by the pheasants - at ages 1, 2, and 3 - and found to be 67.13, 74.88 and $76.12 \%$, respectively. Ipek and Yilmaz (2006) calculated the hatchability of fertile eggs, which they produced during the 1 st and 2 nd incubation period $\left(10^{\lambda}: 8\right.$ 우), to be 74.5 and $81.2 \%$, respectively.

Cetin et al. (1997a) calculated the hatchability to be $62.03 \%$ during the hatching period, which produced pheasants at rate of $1 \delta: 5 q$. Deeming et al. (2011) noticed that pheasants breed at a rate of $1 \delta^{\top}: 7 \%$ in open systems and their hatchability was over $70 \%$ in the first 5 weeks of a 10-week period, then - similar to our study - the efficiency declined. Esen et al. (2010) calculated the hatchability in their 1-, 2- and 3-year old's, at rate of

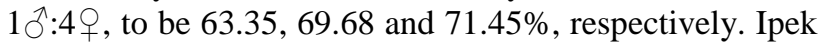
and Yilmaz (2006) noted the hatchability produced by the 
same $1 \delta: 8 \bigcirc$ flock during their 1 st and 2 nd laying periods to be 58.6 and $67.6 \%$, respectively. In reported studies, it is seen that the male: female ratio is not sufficient when based only on fertility. Deeming and Wadland (2002) reported that, for a breeding rate of $1 \delta: 12$, the fertility rate was found to be about $85 \%$, and for a breeding rate of $1 \delta^{\lambda}: 4$, the fertility rate changed from 57 to $75 \%$ (Esen et al., 2010; Genc and Ozbey, 2013). It is seen that there is an increase in hatchability that reached its peak at the 6th week (5th incubation) of the breeding period. Subsequently, while the hatchability of fertile eggs maintained its rate at a certain level, parallel to the decrease in fertility rate, hatchability decreased to reach its lowest level in the last hatching period. Marzoni et al. (2000) obtained semen from the male pheasants that were between 40 to 56 weeks old and they split them into three groups according to the female pheasants' egg production levels ( 1 to 3 weeks, 4 to 11 weeks and 12 to 16 weeks) to evaluate the semen produced by its volume, concentration and viability. They noted that, in transitioning from the first period to the second period, there is a significant increase in the volume and concentration of semen, and there is a huge rise in the number of spermatozoa per ejaculation, whereas in the last period there is a significant decrease in sperm concentration. The decrease in fertility rate can be explained as a libido impairment after the 9th week of the laying period of the pheasants (especially in the male pheasants), which tend to breed seasonally.

The performance of the hatching process for the early, middle, late and pipped death rates were found to be 2.21 , $4.81,5.28$ and $2.86 \%$, respectively. Last-term embryo deaths $(8.14 \%)$ were seen to be the highest death rate (Table 4). At the end of the breeding pheasants' laying period (60th week), the difference between male and female pheasant average body weight is significant $(\mathrm{P}<0.05)$. There is a variation in body weight among both the male and female pheasants. It is considered a significant factor that, among the breeding flock, nothing has been done to ensure uniformity (Table 5).

Table 5 Parent body weights at the end of the laying period $(\mathrm{g})$

\begin{tabular}{c|ccccc}
\hline Age $($ Week) & Gender & $\mathrm{N}$ & Min & Max & $\bar{x} \pm \mathrm{S} \bar{x}$ \\
\hline 60 & Male & 20 & 1240 & 1650 & $1414.5 \pm 105.5^{\mathrm{a}}$ \\
60 & Female & 80 & 730 & 1370 & $1030 \pm 119.4^{\mathrm{b}}$ \\
\hline & Total/Mean & 100 & 730 & 1650 & $1106.9 \pm 193.4$ \\
\hline
\end{tabular}

a.b: According to the Duncan test results, the differences between egg production shown by different letters are remarkable. $(\mathrm{P}<0.05)$.

Deeming et al. (2011) reported early embryo death rates between 4.5 and $5 \%$, and middle to late embryo death rates to be between 15 and $16 \%$ in total at the end of the incubation process, which lasted for 10 weeks with the pheasants they bred in an intensive system. Deeming and Wadland (2001) calculated the embryo deaths of the eggs that they produced from pheasants to be at a rate of $1 \delta^{\lambda}: 8 \bigcirc$ and $1 \delta^{\lambda}: 12$, by dividing them into 6 groups on specific days ( 1 to 4,5 to 8,9 to 12,13 to 16,17 to 20 and 21 to 25$)$. They calculated the death rates which occurred on these specific dates to be - in order -5 to 6,1 to 2,1 to $2,1,1$ to 2 and 14 to $16 \%$. As revealed in the study, it was reported that when higher production was reached, embryo death rates were decreased and, as a result, there was an increase in hatchability (Elibol and Turkoglu, 2014).

Sarica et al. (2003) reported the male and female body weights of some subspecies: Chinese (1000 to $1300 \mathrm{~g}$ ) and American (910 to $1230 \mathrm{~g}$ ) - these weights are lower than our study; Mongolian (1500 to 2000g), Ringed (1320 to $1720 \mathrm{~g}$ ), American Hybrid (1140 to $1480 \mathrm{~g}$ ), Melanistic (1250 to $1620 \mathrm{~g}$ ) and Melanistic Hybrid (1270 to1710g) these weights are higher than our study. It can be said that there is a huge variation among common pheasants regarding their body weights. Cetin et al. (1997a) calculated the body weights of the male and female, mixed Hungarian (Ringed) and Domestic (Caucasian) pheasants, which they used in their study, to be of the order of 1214 to $1430.8 \mathrm{~g}$, although their age was 41 weeks: this rate is higher than our study. It can be said that the main reason why their average weight is higher than our study is because the Caucasin genotype was more abundant in our flock. Usturoi (2008) reported the male and female average body weights to be from 1317.24 to $931.12 \mathrm{~g}$ at the beginning of the 13 -week laying period; at the 5th week - which is the peak - they were from 1339.68 to $983.28 \mathrm{~g}$; whereas at the end of the laying period they were from 1435.35 to $1014.61 \mathrm{~g}$. It is understood that if the average weight at the end of the laying period is taken into consideration, it is similar to our study.

\section{Conclusion}

As a result, for adequate breeding in terms of implemented production systems, light stimulation can be appropriate at the beginning of February if egg production is to be raised. In this way, between February and June, which is the natural production period, more eggs hatch on the farm. There is a need for further research that will present what the expected performance parameters are for the places that are breeding stock pheasants in their natural habitat and showing the adaptation and reproductive levels of pheasants released to the natural environment.

Aktas H. 2009. Türkiye'de hobi amacli olarak yetistirilen bazi sülün türlerinin verim ozellikleri, Yüksek Lisans Tezi, Selcuk Üniversitesi, Saglik Bilimleri Enstitüsü, Konya, in Turkish.

Briganti F, Papeschi A, Mugnai T, Dessi-Fulgheri F. 1999. Effect of testosterone on male traits and behaviour in juvenile pheasants, Ethology Ecology \& Evolution, 11:2, 171-178.

Cetin O, Tepeli C, Kirikci K. 1997a. Sülünlerin (P. colchicus) entansif ortam ve karasal iklimde yetistirilme imkanlarinin arastirilmasi. I. Yumurta verimi ve kulucka ozellikleri. Vet. Bil. Derg. 13, 1;5-10, in Turkish. 
Cetin O, Kirikci K, Tepelı C. 1997b. Sülünlerin (P. colchicus) entansif ortam ve karasal iklimde yetistirilme imkanlarinin arastirilmasi: II. büyüme ve karkas ozellikleri, Vet. Bil. Derg. , 13, 1; 69-76, in Turkish.

Cetin O, Kirikci K. 2000. Alternatif kanatli yetistiriciligi sülünkeklik. SEL-ÜN Vakfi Yayinlari, Konya, in Turkish.

Deeming DC, Wadland D. 2001. Observations on patterns of embriyonic mortality over the laying season of pheasant. British Poultry Science, 42, 580-584.

Deeming DC, Wadland D. 2002. Influence of mating sex ratio in commercial pheasant flocks on bird health and the production, fertility, and hatchability of eggs. British Poultry Science, 43:1, 16-23.

Deeming DC, Hodges HR, Cooper JJ. 2011. Effect of sight barriers in pens of breeding ring-necked pheasants (Phasianus colchicus) II. Reproductive parameters. British Poultry Science, 52:4, 415-422.

Duzgunes O, Kesici T, Kavuncu O, Gurbuz F. 1987. Arastirma ve Deneme Metotlari. Ankara Üniversitesi, Ziraat Fakültesi Yayinlari, Ankara, 381s, in Turkish.

Elibol O, Turkoglu M. 2014. Embriyo gelisimi ve kulucka. Editorler: Türkoglu, M., Sarica, M. Tavukculuk Bilimi (Yetistirme, Besleme, Hastaliklar). Bey Ofset Matbaacilik, 165-206, Ankara, in Turkish.

Esen F, Ozbey O, Genc F. 2010. The effect of age on egg production, hatchability and egg quality characteristics in pheasant (Phasianus colchicus). Journal of Animal and Veterinary Advances. 9 (8): 1237-1241.

Fuller RA, Garson PJ. 2000. Pheasants: status survey and conservation action plan 2000-2004. Page:2

Genc F, Ozbey O. 2013. Sülünlerin (Phasianus colchicus) yumurta verimi ve kulucka ozelliklerine farkli yetistirme sistemlerinin etkisi F.Ü.Sag.Bil.Vet.Derg.; 27 (1): 43 - 47, in Turkish.

Gibes C, Wasilewski M, Lukasiewicz M. 1974. Performance estimation of pheasant flock bred at the state farm Malczewo. Zesz. Nauk. AR Warszawa, Zoot. 10: 181-191. (İn Polish).

Ipek A, Yilmaz DB. 2006. The effect of egg laying period on artificial incubation of pheasants (Phasianus colchicus). World Poultry Science. J.62(suplement): 529-530.

Kirikci K. 2012. Doganin gizemli kuslari sülünler. Dortrenk Yayin Tanitim Matbaacilik Ltd. Sti., Ankara, in Turkish.

Krystianiak S, Kontecka H, Nowaczewski S, Rosinski A. 2007. Laying characteristics of one- and two-year old pheasants (Phasianus colchicus, L.). Folia biol. (Kraków) 55: 65-72.

Kuzniacka J, Bernacki Z, Adamski M. 2005. Effect of the date of egg-laying on the biological value of eggs and reproductive traits in pheasants (Phasianus colchicuc L.). Folia biologica (Krakow), 53: 73-78.
Llanas SG. 2014. Common pheasant. Editors: Baltzer, R., Gunderson, M.M., O’brien, B. ABDO Publishing Company PO Box 398166, Minneapolis, MN 55439, Amerika.

Long JL.1981. Introduced birds of the world. The worldwide history, distribution and influence of birds introduced to new environments. David \& Charles, London.

Marzoni M, Zanobini S, Romboli I, Gazzano A, Ducci M. 2000. Semen characteristics of pheasants during the first reproductive season, British Poultry Science, 41: S1, 20-21

Ozdamar K. (2002). Paket programlar ile istatistiksel veri analizi. Kaan Yayinlari, 4. Baski, Eskisehir, in Turkish.

Pfaff WK, Moreng RE, Klenholz EW. 1990. The utilization of brewers' dried grains in the diets of chinese ringneck pheasant-breeder hens. Poultry Sci.; 69:1491-1495.

Sarica M, Karacay N. 1994. A research on the growth performances and carcass traits of pheasants. Tr. J. Of Vet. and Animal Sciences 18: 371-376

Sarica M, Camci O, Selcuk E. 2003. Bildircin, sülün, keklik, etci güvercin, bec tavugu ve devekusu yetistiriciligi. 3. Baski, Ondokuz Mayis Üniversitesi Ziraat Fakültesi Ders Kitabi, 45-70, Samsun, in Turkish.

Scheid W. 1986. Raising game birds. P.O. Box, 62., Brookfield, WI, 53008-0624

Ucar A, Duman M, Sekeroglu A. 2012. Sülün yetistiriciliginin genel ozellikleri. 8. Ulusal Zootekni Ogrenci Kongresi Bildiri Kitabi: 248-256 (Poster), Sanliurfa, in Turkish.

Usturoi MG. 2008. Reprodüksiyon performance of the adult pheasants, bred under the intensive system. Cercetari Agronomice în Moldova Vol. XLİ, No. 1 (133).

Usturoi A, Vacaru-Opris I, Usturoi MG. 2010. Contributions on the knowledge of incubation eggs produced by adult pheasant females. Lucrari Ştiintifice - vol. 54, Seria Zootehnie.

Wise DR. 1995. Egg production of wild and gamefarm pheasant strains under captive breeding systems. Game Wildl. 12: 321-330.

Woodard AE, Snyder RL. 1978. Cycling for production in the pheasant. Poultry Sci. 57:349-352.

Yamak US. 2015. Artificial breeding of wild birds in Turkey: Partridge breeding case. Indian Journal of Animal Research 49.2: 258-261.

Yannakopoulos AL. 1992. Greek experiences with gamebirds. Poultry Abstr.18:1359.

Yilmaz MR. 2004. Ciftlesme doneminde farkli bicimde yetistirilen sülünlerde (Phasianus colchicus) bazi verim ozellikleri. S.Ü. Saglik Bilimleri Enstitüsü. Doktora Tezi, Konya, in Turkish. 